\title{
The Main Cause of Poor Quality of Education Services in Rural Areas: Teachers and Village Heads
}

\author{
Syarif Makmur ${ }^{1}$, Heri Saksono ${ }^{2}$ \\ Civil Servants of the Government of East Seram Regency of Maluku ${ }^{1}$ \\ Civil Servants at the Ministry of Home Affairs, Research and Development Agency ${ }^{2}$ \\ \{syarifmakmur123@gmail.com ${ }^{1}$, herie.saksono@gmail.com²
}

\begin{abstract}
The purpose of this empirical study is to provide information and analyze the poor quality of education services in 198 villages and 15 subdistricts in the eastern Seram district of Maluku province, and the appointment of teachers as village heads, sub-districts, and structural positions as well as studying the background of their meetings. The method used in this empirical study is to collect data and documents related to the appointment of teachers in other positions, and observation directly in the field, and conduct interviews with several teachers as samples. There were 52 teachers appointed to the village head from the empirical study, three teachers were selected to Camat positions, and six teachers were appointed in echelon two positions. Results of the empirical research were concluded, first: the still poor quality of education services in some villages and sub-districts in the spooky District of the eastern part of Maluku province, the poor quality of education services was one of which was contributed by the appointment of teachers in other positions, there is a political motive to perpetuate the power of the regional head behind the selection of teachers in different situations.
\end{abstract}

Keywords: Quality of Service; Teachers; Village Heads

\section{Introduction}

One of the keys to improving the quality of education is in teachers. Teachers are at the central point of any reform effort in education that leads to qualitative changes (Dharma, 2008). Efforts made in improving the quality of education, among others, curriculum changes, the development of teaching methods, as well as the provision of facilities and infrastructure (Astuti, 2009), the efforts made to improve the quality of education will not be meaningful if without involving teachers in it (Merchant \& Idrus, 2009). The results of the Program for international student assessment (PISA) survey, which is a global activity of the Organization for economic cooperation for development (OECD) for student skills assessment programs in mathematics, language, and science. The survey ranked Indonesia 72nd out of 77 countries and still below Malaysia, Brunai, Vietnam, and the Philippines.

Indonesia's position under ASEAN countries is certainly contributed by regions with low education systems and quality. And one of the most significant contributors is the spooky District of the eastern part of Maluku province. The quality of education services in 198 (one 
hundred and ninety-eight) villages and 15 (fifteen) subdistricts in the Seram district of the eastern part of Maluku province over time experienced a significant decrease. The decline was caused by many things, both internally and externally.

Lack of facilities and infrastructure, uneven distribution of teachers, geographical conditions of less supportive areas, low teacher benefits, and various problems almost every year faced by the local Government of the eastern Seram district. The Regional Budget (APBD) annually has set aside 20 percent of the total budget for education. Still, this area stagnates in education services, mainly primary and secondary education in villages and subdistricts. Although this eastern Seram district's age has entered 15, this area is still far behind compared to other expansion areas in Indonesia. It falls into the category of the disadvantaged regions in Indonesia. This low education service was causing the human development index or human development index of eastern Seram districts below the national average, even the weakest of all neighborhoods/cities in Maluku province.

This education process, ranging from elementary school level to junior high school level, has not shown any leap in achievements achieved by other schools in Indonesia. The quality of education services still said to be quite good is in the District's capital, namely in the Bula sub-district. Compared with the quality of education services in other district capitals in Maluku, let alone the wealth of districts in Java and Sumatra, eastern seram districts are still far behind. Many elementary and junior high school teacher appointments in the east Seram district to be the village head is a unique and exciting concern to be reviewed and analyzed.

The quality of education services is the key to the progress of a region, even a nation. As Niryana (2008) stated, education is one of the most important aspects of a nation's progress. A sound education system will produce quality human resources that will also improve the community's quality of life. No wonder that developed countries today have quality human resources created by a sound education system. But which countries with the best education systems in the world? As quoted from Google scholar, There countries are: English, Preschool education in England starts from the age of 3, and the acceptance rate is very high.

There puts the UK ahead of all developed countries in the OECD. Meanwhile, for higher levels of Education, Uk students tend to take up maths and science. The UK's education system is highlighted and considered successful because the country has a low unemployment rate, although the standards applied to work are relatively high. There is based on an education system that emphasizes practice rather than theory. The UK is one of the highest scorers in Pisa (Programme for International Student Assessment). The OECD organizes PISA (Organisation for Economic Co-operation and Development) held once every three years for 15 -year-old school students. The goal is to improve the methods of education as well as the results obtained from it German.

Germany is one of the countries that are serious about making policies in the field of education. The Government requires every citizen without exception to complete formal education up to the intermediate level. While at the higher education level, Germany applies free education to its citizens who continue their higher education in government-owned institutions. With this, Germany sought to suppress education's commercialization so that more and more citizens attended the college level. The country called the country of these inventors received a lot of appreciation for it. Germany's dedication to education paid off because it achieved scores above the OECD countries' average in PISA 2018.

The United States. Like the UK, America is among the countries with scores above the average of OECD countries. One of the critical things that matter in this regard is the studentfocused learning system. Therefore, students in this country have known problem-solving and project-based education since they were in school. Singapore. Neighboring Singapore is a 
developed country and one of the countries with the world's best education system. Singapore's Education System is considered superior to the achievements of its students in PISA by the OECD. In the most recent PISA 2018, Singaporean students were judged to outperform the United States in mathematics. They were rated well in the exams of young students spread across the world's top universities. One of the things that supports this achievement is how Singapore "invests" in teachers or teachers in their country. The profession of teachers in the country is paid very decently, and a strict selection process is imposed in its recruitment. As such, only qualified teachers teach in schools in Singapore. Australia. Australia is one of the countries with the best education system in the world. In general, the Government is perfect in terms of access, quality, and human resources. No wonder many people from all over the world migrate to this country to continue their education and then look for opportunities to start a career there.

Meanwhile, higher education in Australia has been named among the world's best universities in recent years. In addition to 5 (five) Countries with the best system globally, Perhaps too far we compare the quality of education in the eastern Seram district with the quality of education in 5 (five) the world's best countries. The quality of education in Indonesia is still far behind. As quoted from google scholar - In the education quality survey issued by PISA, Indonesia ranked 72 nd out of 77 countries. Observers consider low teacher competence and an overly archaic education system to be the cause.

The student capability survey released by the Programme for International Student Assessment (PISA) on Tuesday (3/12) in Paris ranked Indonesia 72nd out of 77 countries. This data makes Indonesia ranked in the bottom six, still far below neighboring countries such as Malaysia and Brunei Darussalam. The PISA survey is a reference in assessing the quality of education globally, which assesses reading, maths, and science skills. Why is the quality of Indonesian education so poor? Competence of teachers and systems that shackle. According to education observer Budi Trikorayanto, there are at least three problems that still shackle Indonesian Education:

\section{a) Teacher Quality}

Teacher competence in Indonesia is still at a deficient level. To produce intelligent students, competent teaching resources are required. Number one is the factor that can make a child bright or not is the teacher. So indeed, our teachers' competence is very low. It can be seen from the results of the Teacher Competency Test (UKG) that the value is below five on average.

\section{b) Shackling Education System}

In the era of education 4.0, teachers should no longer be the prominent 'resource persons' in the learning system but rather as mentors, encouragements, and facilitators. If the 4.0 education system wants to succeed, students must now be educated to become more active. "So we still adhere to mass education, schools are still 'factories,' it's education 2.0. We have been educated 4.0 that has been the era of artificial intelligence (AI) is no longer a factor," he told DW Indonesia. Budi expects more educated children to actively learn and find out something from other sources outside of school, for example, through verified sites and have credibility on the internet. Moreover, each child has a different character. They will become brighter when they learn something about their interests and talents. 


\section{c) Educational Institutions Need Improvement}

Menekan the need to improve the quality of educational institutions that print quality teachers in the future. He exemplified one of them, the Institute of Teacher Training and Education (IKIP). "IKIP campuses, whose teaching model like that makes teachers less have ideas of creativity and less explore with academics. So every year when there is a Teacher Competency Test (UKG), their results are always low," he said. Pisa research shows that Indonesia has 371 for reading, 379 for mathematics, and 396 for science.

Indonesia lags behind Malaysia in 56th place, with scores of 415 for reading, 440 for mathematics, and 438 for science. Meanwhile, Singapore ranks in the top two because it has a mature education system. "In Singapore, the teacher award is very high, and the requirement to become a teacher is also not arbitrary. So if you're not very smart, you can't be a teacher. If you want to learn, it's hard to be a teacher. But they also get a very satisfactory return," he said. Budi reaffirmed that several problems faced by Indonesia, such as teacher welfare, ultimately boil down to the competence of a teacher or teacher himself. "Singapore does emphasize hard work. So it's not reducing the hours of study if I see.

If we emphasize faith and taqwa and happy children, that's a hassle too. Learning is something serious and needs discipline, not so that the child looks happy, and the child has faith and holiness," he explained. Budi added that Indonesia's education system is still too oldfashioned or called 'feudalistic,' so it lacks respect for freedom of thought. Budi said that the Minister of Education and Culture (Mendikbud) Nadiem Makarim should dare to simplify the curriculum and reduce the rules and shackles to create freedom of education. "So the feudalistic must be eliminated there must be equality must be open source.

I think Nadiem started five years and will not be able to stop again. He has opened the gate and must be implemented," he said. Since being appointed as Minister of Education and Culture (Mendikbud), Nadiem Makarim has new proposals to advance Indonesian education, such as creating competency-based education and character. His suggestion is now under review at the Ministry of Education. "The role of technology will be huge in everything, the quality, efficiency and administration of an education system of this magnitude yes," concluded Nadiem, as reported from Tirto. He also responded that Pisa survey results should not be ruled out. Just this survey is a reference to improve the quality of Indonesian education for the next five years. "Pisa assessment results are a valuable input to evaluate and improve the quality of Education in Indonesia, which will focus on the Government for the next five years. Emphasizing the importance of competence to improve the quality to face the challenges of the 21st Century," Nadiem said in his statement.

The trend of the times has changed in a more digital direction. Indonesia needs to urgently improve and meet the 4.0 education target to create intelligent and ethical human beings. No need to compare with other countries. We compare with other districts in Indonesia, for example, Lombok West Nusa Tenggara. As a Google scholar, the quality of education in the area has led to the education system 4.0. even schools in Lombok are already oriented towards world-class schools how the quality of education in the eastern Seram district has been far behind for a long time. Some primary and secondary school teachers' appointment to be village heads is unique and exciting to review the positive and negative impact.

As explained above, the quality of education services in 198 villages and 15 sub-districts is deficient in the heavy again many teachers are appointed as village heads. The teachers should be given the task to focus on teaching in the classroom, given more responsibility to take care of the village government's administration to ensure that the school's teaching and learning 
process can not run as it should. The quality of human resources produced is not qualified and challenging to compete with human resources in Indonesia's other regions.

The management of the system and the quality of education in the eastern Seram district is still politically motivated according to the tastes of the head of the region, which is oriented to perpetuate their power. This fact is strengthened by the appointment and dismissal of the head of the eastern Seram district's education office as the technical person in charge of education considers many aspects of politics. Also, the policy's derivative makes the appointment and dismissal of principals very loaded with political content. As concrete evidence and facts in the field, already two heads of the eastern Seram district's education office became convicted of corruption of education funds. Both have been dismissed disrespectfully as ASN under the provisions of the prevailing laws and regulations.

This fact is indisputable, and it has become a public discussion in the eastern Seram district that the appointment, transfer, and dismissal of the head of the education office, the head of the education service unit in the sub-district, and also the principals are still considering the political aspects to perpetuate the power of the regional leader. The number of teachers is quite a lot more than $40 \%$ of the number of ASN has a very strategic political potential in every regional head election event. Teachers and ASN's impartiality in local elections is the beginning of the collapse of a professional, neutral and prosperous bureaucracy. There will be no experienced teachers, apathetic teachers, and profitable teachers in this District if the District's head is still oriented to political interests in education governance in the eastern seram district. More fatal and severe, some teachers initially taught in schools in the structural positions of both echelon two and echelon three.

\section{Methodology}

To find out the facts and data and information about the poor quality of education services in the eastern Seram district, data and information can be seen in the survey of the Central Bureau of Statistics (BPS) east seram district in 2019 (Cosby, 2008). From several key indicators showed that the school participation rate, the number of teachers, facilities and infrastructure, and graduates produced showed that the eastern Seram district was ranked below with a low category along with 3 (three) other districts, namely the western Seram district, Aru district, and southwest Maluku district.

Furthermore, to obtain data and documents related to teachers' appointment in principal, Camat positions, and other positions are conducted a direct review at the village government office and interviews directly with several teachers. From 198 villages and 15 sub-districts in the eastern Seram district, 52 teachers were appointed as village heads, appointed as Camat three people, and appointed as other structural officials six people. The data and facts in the field prove that teachers' appointment in principal, camat positions, and different structural positions are the cause of poor quality of education services in the eastern Seram District. As the OECD and PISA report on students' maths, language and science put Indonesia in 72nd place out of 77 countries. It is almost sure that the contribution was made by regions in Indonesia whose quality of education is low. One of those areas is the spooky Eastern District. 


\section{Result and Discussion}

Indonesia's position in the $72 \mathrm{nd}$ out of 77 countries related to the quality of education became an interesting discussion about what strategies and solutions Indonesia need to do to match other countries, especially ASEAN. There must be a national drive (Soewardi, 2001) to address this, and it cannot be entirely handed over to the Government. Most of the contributions were contributed by regions in eastern Indonesia: Maluku, Papua, and West Papua. And it can be confident that the poor quality of education is the contributor to the poor quality of Indonesian education in seram regency in the eastern part of Maluku. It all has to start with the quality of education as Germany, Japan, England, and Singapore does. Why does Singapore excel in the quality of education services at the world level? according to Damayanti (2008) and Dharma (2008), One of the things that supports this achievement is how Singapore "invests" in teachers or teachers in their country.

The profession of teachers in the country is paid very decently, and a strict selection process is imposed in its recruitment. Only qualified teachers in Singapore are the primary critical human resources that have national and even international competitiveness. Theoretically, as Niryana (2008) stated, education is one of the essential aspects of a nation's progress. A sound education system will produce quality human resources that will also improve the community's quality of life. According to Astuti (2009) and Dharma (2008): it is not surprising that developed countries today have quality human resources produced by a sound education system.

As reported by google scholar, PISA's education quality survey, Indonesia ranked 72nd out of 77 countries. Dharma (2008) considers low teacher competence and an overly ancient education system to be the cause. Why mathematics, language, and science are indicators used by the Organization for education cooperation development (OECD) to assess students' abilities the student and student skills survey released by the Programme for International Student Assessment (PISA) in Paris ranks Indonesia 72nd out of 77 countries. This data makes Indonesia ranked in the bottom six, still far below neighboring countries such as Malaysia and Brunei Darussalam.

According to Muhammad (2010), the PISA Survey is a reference in assessing the quality of education globally, which evaluates reading, mathematics, and science. Education Minister Nadien Makarim, in a press conference, presented new proposals to advance Indonesian education, such as creating competency-based and character-based education. His suggestion is now under review at the Ministry of Education. "The role of technology will be huge in everything, the quality, efficiency and administration of an education system of this magnitude yes," as reported from Tirto. He also responded that Pisa survey results should not be ruled out. Just this survey is a reference to improve the quality of Indonesian education for the next five years. From the data and facts, both globally and regionally, Indonesia's quality of education services is still far behind other countries, ranked 72 nd out of 77 countries.

Areas contributed to indonesia's position in the $72 \mathrm{nd}$ out of 77 countries with poor quality and education system, and the contribution certainly was one of them given by the eastern Seram district. The eastern Seram district contributed extensively enough that Indonesia ranked 72 nd out of 77 countries with a noticeable and very factual indicator, namely with the discovery of facts there are approximately 52 teachers concurrently as village heads, three teachers appointed as Camat and six teachers appointed in structural positions at echelon two and echelon 3 . The facts show that there will not be a correct and good quality of education services in the eastern seram district if a number of teachers who are very potential are not returned to the classroom or study room that is indeed skilled in providing lessons educating 
students. If this condition is allowed, Indonesia will continue to be at the bottom, and difficult to rise and compete with other countries. It also illustrates that the eastern Seram district will continue to be under other areas in Indonesia if the very potential teachers are not returned to the classroom as their habitat to teach, motivate and be a companion for studying science.

\section{Conclusion}

From the theoretical descriptions, analysis, and facts mentioned above, the result is that the appointment of 52 teachers as village heads, three teachers as Camat, and six teachers as service heads and section heads have a terrible impact on education services in eastern seram districts, which will further impact Indonesia's position under other countries. This consequence will continue to be a heavy burden for Indonesia, especially disadvantaged areas such as eastern seram districts that are still very weak in their human resources, the quality of their education infrastructure, and the minimal education budget.

From the above results can be concluded first: the poor quality of education services in many villages and sub-districts in the spooky District of the eastern part of Maluku province will have an impact on the quality of human resources that will be produced for the present and the future, where they will not be able to compete with human resources in other regions in Indonesia even to the second world level: the poor quality of education services is one of which is contributed by the appointment of teachers in different positions that teachers should be in the classroom to provide knowledge and knowledge to students.

Third: there is a political motive to perpetuate the power of the regional head behind teachers' appointment in other positions. Ideally, the teachers only focus on the technical affairs of education. Instead, they are busy with other administrative matters that are not their competence, let alone teachers should be preoccupied with political affairs to perpetuate the head of the region's authority. There reduce their ethics and professionalism as teachers and will impact the worsening quality of education services.

\section{References}

[1] Astuti, Ika Widi, 2009, "Kompetensi Profesional Guru Pendidikan Agama Islam Madrasah Aliyah Al-Hikmah Gunung Kidul”, UIN Sunan Kalijaga [On-line], Abstrak dari: Perpustakaan Digital UIN Sunan Kalijaga Yogyakarta, (http://digilib,uinsuka,ac,id/ gdl,php?mod=browse\&op=read\&id=digilib -uinsuka-ikawidiast-2077)

[2] Bappenas, 2009, "Perilaku Individu dalam Membentuk Kualitas Kinerja yang Baik", Dalam http://goodgovernance,bappenas,go,id/publi kasi_files/modul/modul_gg2.pdf

[3] Cozby, Paul C, 2008, "Methods In Behavioral Research Edisi 9", Yogyakarta: Pustaka Pelajar,

[4] Damayanti, Ninin, 2008 "Indeks Pembangunan Manusia Indonesia Terendah di Asia".

[5] Dharma, Surya, 2008 "Penilaian Kinerja Guru" Dalam http://lpmpjogja,diknas,go,id/materi/fsp/200 9-Pembekalan-Pengawas/22\%20-\%20KODE\%20--\%2004\%20- \%20B3\%20Penilaian\%20Kinerja\%20Guru, pdf

[6] Fatah, N, 1996, "Landasan Manajemen Pendidikan”, Bandung: Remaja Rosdakarya, Bandung, 
[7] Iskandar, 2009, "Psikologi Pendidikan Sebuah Orientasi Baru”, Gaung Persada Press, Cipayung,

[8] Kasinda, Mahardian Catur, 2010, "Hubungan Kompetensi professional dan Motivasi Kerja dengan Kinerja Guru di SMKN 6 Malang”, Universitas Negeri Malang [On-line], Abstrak Skripsi Jurusan Teknik, Universitas Negeri Malang, (http://karyailmiah,um,ac,id/index,php/TM/article/view/ 4990).

[9] Landy, Frank J \& Conte, Jeffrey M, 2004, "Work in The 21 ST Century an Introduction to Industrial and Organizational Psychology", McGraw- Hill, New York, 2004.

[10] Makmur, Syarif, 2008, "Pemberdayaan Sumber Daya Manusia dan Efektifitas organisasi : Kajian Penyelenggaraan Pemerintahan Desa”, PT, RajaGrafindo Persada, Jakarta,

[11] Muhammad, Djibril, 2010, "Indeks Pembangunan Manusia Indonesia Jauh di Bawah Malaysia" dalam http://www,republika,co,id/berita/breakingnews/nasional/10/12/10/151576-indeks- pembangunan-manusia-indonesia-jauh-dibawah-malaysia

[12] Mukhlis, 2009, "Profesionalisme Guru Menyongsong masa Depan" dalam http://mukhliscaniago,wordpress,com/2009/ 10/26/profesionalisme-kinerja-gurumenyongsong-masa-depan-presented-by- mukhlis/

[13] Mulyani, Anita, 2009, "Hubungan antara Kompetensi Profesional Guru dan Kepuasan Kerja dengan Kinerja Guru", Universitas pakuan Bogor [On-line], Abstrak Tesis Program Pascasarjana Universitas Pakuan, (http://www,pasca- unpak,ac,id)

[14] Mulyasa,E, "Menjadi guru professional menciptakan pembelajaran kreatif dan Hubungan Antara Kompetensi Profesionalisme Guru Dan Kinerja Guru Di Sma Xxx Tangerang Jurnal Psikologi Volume 9 Nomor 2, Desember 201180 menyenangkan",

[15] Rosdakarya, Bandung, 2005 N, S, "Hubungan Pemahaman Kompetensi dengan Kinerja Guru Sekolah Dasar Yayasan Joseph Yeemye”, FKIP Unika Atma Jaya, Jakarta [Online], Abstrak Tesis FKIP Unika Atma Jaya, Jakarta, 2008 (http://lib,atmajaya,ac,id/default,aspx?tabID =61\&rc=k\&id=151113)

[16] Ningsih, Suprapti, 2009, "Pengaruh Aspek Kompetensi Profesionalisme terhadap Kinerja Guru Ekonomi (Studi Pada Guru Bersertifikasi di Kota Kediri)”, Universitas Negeri Malang [On-line], Abstrak Skripsi Universitas Negeri Malang, (http://karyailmiah,um,ac,id/index,php/ekonomi- pembangunan/).

[17] Saudagar, Fachruddin \& Idrus, Ali, 2009, "Pengembangan Profesionalitas Guru", Gaung Persada Press, Cipayung-Ciputat.

[18] Stafmm, 2008, “Analisis tentang Kompetensi Professional Guru, MPMBS, Sarana, dan Prasarana Pendidikan terhadap Kualitas Sekolah SMPN1 Kawunganten Kabupaten Cilacap" dalam http://mm,unsoed,net

[19] Supardi, Darwyansyah, Sutomo,, \& Supriyadi, Edi, 2009, "Profesi Keguruan Berkompetensi dan Bersertifikat", Jakarta: Diadit Media Syah,Muhibbin, "Psikologi Pendidikan dengan Pendekatan Baru", Rosdakarya, Bandung, 2010

[20] Tempe, A, Dale, 1992, "Kinerja", Jakarta: PT, Gramedia Asri Media, Jakarta,

[21] Tika, H, Moh, Pabundu, 2005, "Budaya Organisasi dan Peningkatan Kinerja Perusahaan", Jakarta: Bumi Aksara, Jakarta,

[22] Ulfah, Gusti Sari Nadia, 2006, "Implementasi KBK Dalam Proses Pembelajaran Aqidah Akhlak Di Sdi Darunnajah Ulujami”, Jakarta: tidak diterbitkan dalam http://idb4,wikispaces,com/file/view/ss4008 
$=$ com_content\&view $=$ article $\&$ id $=56664$ :ind $\quad$ eks-pembangunan-manusia-indonesianaiktipis \&catid $=18 \&$ Itemid $=95$

[23] Wibowo, 2009, "Manajemen Kinerja Edisi Kedua”, Rajawali Pers, Jakarta,

[24] Widodo, 2005, "Cerdik Menyusun Proposal Penelitian Skripsi, Tesis, dan Disertasi”, Magna Script, Jakarta, 2005

[25] Winarsunu, Tulus, 2007, "Statistik dalam Penelitian Psikologi dan Pendidikan”,Edisi Revisi, UMM Press, Malang, 2007. 